\title{
COMPARATIVE INVESTIGATION OF DIFFERENT METHODS FOR THE DETECTION OF INFECTION IN RABBITS CHALLENGED WITH $L$. interrogans SEROTYPE hardjo
}

\author{
Živoslav Grgić ${ }^{1}$, Bosiljka Đuričić ${ }^{2}$, Branka Vidić ${ }^{1}$, Sara Savić ${ }^{1}$, Ivan Pušić ${ }^{1}$ \\ ${ }^{1}$ Scientific Veterinary Institute „Novi Sad“, Novi Sad, R. Srbija. \\ 2 Faculty of Veterinary Medicine Beograd, University \\ of Beograd, Beograd, Republic of Serbia.
}

\section{Abstract}

Keeping up-to-date with modern diagnostic techniques for leptospirosis as well as continuous improvement of laboratory diagnostic methods resulted in abundant knowledge on the nature and consequences of this infection and its importance in both human and veterinary medicine. In that respect, development and introduction of novel diagnostic tests and procedures have become the paramount issue in the diagnostics of leptospirosis and related infectious diseases. Thus, the goal of this research was to investigate the application of diverse laboratory methods and to evaluate their validity in the diagnostics of leptospirosis. Eleven rabbits were artificially infected with live cultures of $L$. interrogans serovar hardjo by the method of skin scarification. Blood and blood serum samples of challenged animals were collected every other day throughout the 3 -week period (i.e. until day 21), and then once weekly during following five weeks. Blood sera were tested for the presence of $L$. interrogans serovar hardjo specific antibodies applying the methods of microscopic agglutination (MA) test and ELISA. Blood samples were examined using the method of cultivation in liquid medium by Johnson supplemented with $200 \mu \mathrm{g} / 1 \mathrm{ml} 5$ - fluorouracil (5-FU). Presence/absence of L.interrogans serovar hardjo was confirmed by polymerase chain reaction $(P C R)$ method. In this reaction, a pair of primers separated from the basic structure of the Leptospira interrogans rrs (16S) gene. In MA test, the presence of specific antibodies against $L$. hardjo in rabbits was confirmed in $67(36.61 \%)$ of 183 investigated sera. Initial positive specific antibody finding was recorded on day 9 post challenge, and it persisted until day 17. In ELISA test, positive and suspect findings 
were confirmed in 67 and 18 samples, respectively. Initial ELISA-positive finding was observed on day 15 , showing increasing tendency throughout the monitoring period and reaching its maximum value on day 42 . Method of blood sample cultivation resulted in isolation of $L$. interrogans serovar hardjo in $33(18.03 \%)$ on day 3 at the earliest, whilst highest isolation rate was observed on day 17 post challenge. Applying polymerase chain reaction (PCR) method, genome or genome sequences of $L$. interrogans serovar hardjo were detected in 67 (56.30\%) out of 119 blood serum samples. PCR method revealed positive finding as early as on day 1 post challenge, whereas the highest rate of positive findings was recorded on day 19. Comparison of the results obtained by methods of cultivation and PCR during the period from experimental day 1 to 21 , i.e. period prior to administration of chemotherapeutic agents, demonstrated high level of linear correlation of $r=0.8105$ at the 0.01 significance level. After dihydrostreptomycin therapy administered from day 21 post infection, $L$. interrogans serovar hardjo could not be isolated using the method of blood sample cultivation. Contrary to that, PCR method revealed the presence of $L$. interrogans serovar hardjo genome in 23 samples.

Key words: Leptospirosis, diagnostic methods, $L$. interrogans serovar hardjo

\title{
UPOREDNO ISPITIVANJE RAZLIČITIH METODA ZA DOKAZIVANJE INFEKCIJE VEŠTAČKI INFICIRANIH KUNIĆA SA L. interrogans SEROTIP hardjo
}

\author{
Živoslav Grgić́1, Bosiljka Đuričić², Branka Vidić1, Sara Savić ${ }^{1}$, Ivan Pušić ${ }^{1}$ \\ ${ }^{1}$ Naučni institut za veterinarstvo „Novi Sad“, Novi Sad, R. Srbija. \\ ${ }^{2}$ Fakultet veterinarske medicine Beograd, Univerziteta \\ u Beogradu, Beograd, R. Srbija.
}

\section{Kratak sadržaj}

Praćenjem savremenih metoda dijagnostike leptospiroze, a posebno usavršavanjem laboratorijskih dijagnostičkih metoda, došlo se do brojnih saznanja o prirodi i posledicama ove infekcije, o njenom zdravstvenom značaju kako u veterinarskoj tako i humanoj medicini. Sve ovo ima za posledicu nastojanje da se u dijagnostici zaraznih bolesti kakva je i leptospiroza, razvijaju i uvedu novi dijagnostički testovi i procedure. Imajući u vidu sve navedeno, kao cilj ispitivanja postavljena je potreba da se ispita primena ra- 
zličitih laboratorijskih metoda i oceni njihova valjanosti u dijagnostikovanju leptospiroza. U ogledu je veštački inficirano postupkom skarifikacijom kože, 11 kunića živom kulturom L. interrogans serovar hardjo. Kunićima su uzeti uzorci krvi i krvnog seruma, svakog drugog dana do 21. dan, a zatim 1 nedeljno narednih 5 nedelja. Krvni serumi su ispitani na prisustvo specifičnih antitela protiv L. interrogans serovar hardjo metodima mikroskopske aglutinacije (MA) i ELISA. Uzorci krvi su ispitani metodom kultivacije na tečnoj hranljivoj podlozi po Johnson-u sa dodatkom $200 \mu \mathrm{g} / 1 \mathrm{ml} 5$-fluorouracila (5-FU), a prisustvo/odsustvo genoma L.interrogans serovar hardjo metodom lančane rakcije polimeraze $(P C R)$. U reakciji je korišćen par prajmera izdvojen iz osnovne strukture Leptospira interrogans rrs (16S) gena. Specifičnih antitela protiv L. hardjo kod kunića primenom MA utvrđena su kod 67 uzoraka seruma ili 36,61\% od ukupno ispitanih183, pozitivan nalaz specifičnih antitela najranije je zabeležen 9. dana od inficiranja i održavao se do 17. dana. Primenom ELISA testa pozitivni nalazi utvrdeni su kod 67, a sumnjivi kod 18 uzoraka. Najraniji pozitivan nalaz ELISA testom zabeležen je petnaestog dana, a zatim broj pozitivnih nalaza raste, dostiže maksimum 42. dana. Metodom kultivacije uzoraka krvi, L. interrogans serovar hardjo je izolovana kod $33(18,03 \%)$ uzorka, najranije trećeg dana, a najveći procenat izolata zabeležen je 17. dana od inficiranja. Primenom metoda lančane reakcije polimeraze ( $P C R$ ) genom ili delovi genoma $L$. interrogans serovar hardjo dokazan je u krvnom serumu kod 67 (56,30\%) od 119 uzoraka. Primenom metoda lančane reakcije polimeraze $(P C R)$ pozitivan nalaz zabeležen je već prvog dana, a najveći procenat pozitivnih nalaza zabeležen 19. dana od inficiranja. Poredeći rezultate dobijene metodom kultivacije i PCR počev od 1. do 21. dana eksperimenta odnosno za period pre prmene hemioterapeutika, ustanovljen je visok nivo linearne korelacije od $r=0,8105$ na nivou značajnosti od 0,01 . Nakon primene dihidrostreptomycine od 21. dana nakon inficiranja, u uzorcima krvi kunića metodom kultivacije nije izolovana $L$. interrogans serovar hardjo. Za razliku od metoda kultivacije, primenom PCR metoda, dokazana je prisustvo genoma L. interrogans serovar hardjo kod 23 uzorka.

Ključne reči: Leptospiroza, metodi dijagnostike, $L$. interrogans serovar hardjo 


\section{INTRODUCTION}

Most cases of $L$. interrogans serotype hardjo infection in animals are asymptomatic, yet associated with shedding of leptospires in the environment via the urine. Identification of infected animals, particularly carriers, is a multifaceted problem in the view of validity of applied serological tests as well as highly complex and time-consuming isolation procedure. Keeping up-to-date with modern diagnostic techniques for leptospirosis as well as continuous improvement of laboratory diagnostic methods resulted in abundant knowledge on the nature and consequences of this infection and its importance in both human and veterinary medicine. In that respect, development and introduction of novel diagnostic tests and procedures have become the paramount issue in the diagnostics of leptospirosis and related infectious diseases. Thus, the goal of this research was to investigate the application of diverse laboratory methods and to evaluate their validity in the diagnostics of leptospirosis. Immunological assays are highly applicable in the diagnostics of leptospirosis and thus increasingly used in laboratory practice. Reaction of microscopic agglutination (MA), being an eligible diagnostic method, has been the most widely used serological test so far. In the recent years, ELISA has become widely used. However, all the aforementioned tests demonstrated some limitations and drawbacks regarding sensitivity and specificity in the detection of subclinical infections in animals. While the method of isolation is the most accurate and reliable diagnostic tool yet highly demanding, time-consuming and expensive, the polymerase chain reaction (PCR) is sufficiently sensitive, specific and rapid method enabling detection of even small number of leptospires. Capacity of polymerase chain reaction (PCR) to detect presence of 5-10 bacteria per $m l$ of the sample indicates its high sensitivity, which makes it more appropriate and applicable as compared to the method of cultivation Smith et al. (1994).

\section{MATERIAL AND METHODS}

Population of 11 rabbits were challenged with live culture of $L$. interrogans serovar hardjo by skin scarification procedure. Blood and blood serum samples of challenged animals were collected every other day throughout the 3 -week period (i.e. until day 21), and then once weekly during following five weeks. Blood sera were tested for the presence of $L$. interrogans serovar hardjo specific antibodies applying the method of microscopic agglutination (MA) test with live seven-day-old cultures of reference leptospiral serotypes (Royal Tropical Institute Amsterdam, The Nederland) as well as modified ELISA for 
detection of $L$. hardjo-specific antibodies in blood serum samples of infected rabbits. In this assay, basic components of the commercial bovine kit were used (IgG and IgM, producer: Central Diagnostic, Lelystad, the Netherlands A). The modification has implicated replacement of the conjugate with anti-rabbit immunoglobulins ( $\operatorname{Ig} G, \operatorname{IgA}$, $\operatorname{Ig} M$ ) produced in pig and conjugated with peroxidase (MP Biomedicals, Inc; Aurora, Ohio SAD, cat. No 1135). The titre of used immunoglobulins was determined by chessboard titration. The working titre of conjugated immunoglobulins was 1:200. Detection of $L$. hardjo in blood serum was performed by the method of cultivation in liquid medium (by Johnson) supplemented with bovine albumin and $200 \mu \mathrm{g} / \mathrm{ml} 5$ fluorouracil (5FU) and by polymerase chain reaction $(P C R)$. The reaction was done according to adapted protocol for isolation and diagnostics of leptospiral DNA described by Merien et al. (1992). Isolation of DNA from urine samples was performed according to QIamp DNA Mini and Blood Mini Kit (Quiagen', Germany) protocol for DNA purification from blood and body fluids (spin-protocol). PCR reaction was accomplished using two oligonucleotide primers described by Mrerien et al. (1992), which correspond to nucleotides 38-57 A Lepto (5'-GGC GGC GCG TCT TAA ACA TG-3') and B Lepto (5'-TTC CCC CCA TTG AGC $\left.A A G A T T-3^{\prime}\right)$ from the primary structure of $L$. interrogans serotype canicola strain Moulton $16 \mathrm{~S} r R N A$ gene. The resulting specific product was $331 \mathrm{bp}$ in size. DNA amplification was performed in a $25 \mu \mathrm{l}$ reaction, using a thermal cycler "MultiGene Thermal Cycler, TC9600-G" manufactured by LabnetInternational, Inc (NY., USA). Temperature regimen encompassed 15-minute Taq polymerase activation period at $95{ }^{\circ} \mathrm{C}$ with simultaneous phase of initial denaturation of DNA template from the sample, followed by 35 cycles encompassing 1.5-minute denaturation at $94^{\circ} \mathrm{C}, 1$-minute hybridization (annealing) at $63^{\circ} \mathrm{C}, 2$-minute elongation at $72{ }^{\circ} \mathrm{C}$ and final elongation (extension) at $72{ }^{\circ} \mathrm{C}$ during 10 minutes. The resulting amplification product was applied onto the $1.5 \%$ gel supplemented with ethidiumbromid and subjected to electrophoresis. The results were captured and interpreted using the illuminator.

\section{RESULTS AND DISCUSSION}

The results of the detection of specific antibodies against $L$. hardjo in rabbits using dark field microscopic agglutination (MA) are displayed in Table 1 and Chart 1 . The results pertain to the period from the start of the experiment until day 56, i.e. the experimental period is divided into two phases. The first phase encompassed sampling from day 1 to day 21, whereas second phase encompasses weakly sampling throughout 5 -week period after administration of chemotherapeutic agents. 
Table 1. Finding of antibodies against $L$. hardjo in blood serum of rabbits challenged by skin scarification (microscopic agglutination method, MA)

\begin{tabular}{|c|c|c|c|c|c|c|c|c|c|c|c|c|c|c|c|c|c|}
\hline \multirow{2}{*}{ 宽 } & \multicolumn{12}{|c|}{ Days post infection } & \multicolumn{5}{|c|}{ Days post therapy } \\
\hline & 0. & 1. & 3. & 5. & 7. & 9. & 11. & 13. & 15. & 17. & 19. & 21. & 28. & 35. & 42. & 49. & 56. \\
\hline 1 & - & & - & - & $1: 100$ & $1: 100$ & $1: 100$ & $1: 100$ & $1: 250$ & $1: 100$ & $1: 50$ & $1: 25$ & - & . & 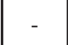 & - & . \\
\hline 2 & - & & - & 1:25 & $1: 50$ & 1:100 & $1: 100$ & $1: 100$ & $1: 250$ & $1: 100$ & $1: 25$ & $1: 25$ & $1: 25$ & - & - & - & - \\
\hline 3 & - & & - & - & $1: 25$ & $1: 50$ & 1:50 & $1: 100$ & $1: 100$ & $1: 100$ & $1: 25$ & $1: 25$ & - & - & $1: 50$ & $1: 25$ & $1: 25$ \\
\hline 4 & - & 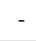 & $1: 50$ & 1:100 & $1: 250$ & $1: 500$ & $1: 250$ & $1: 500$ & $1: 500$ & $1: 100$ & $1: 100$ & $1: 100$ & $1: 100$ & $1: 75$ & $1: 75$ & $1: 50$ & $1: 25$ \\
\hline 5 & - & - & - & 1:100 & $1: 500$ & 1:100 & $1: 250$ & $1: 100$ & $1: 250$ & $1: 100$ & $1: 50$ & $1: 50$ & $1: 50$ & $1: 25$ & $1: 25$ & $1: 25$ & $1: 25$ \\
\hline 21 & - & - & - & - & $1: 50$ & 1:100 & $1: 250$ & $1: 250$ & $1: 250$ & $1: 250$ & $1: 100$ & $1: 100$ & $1: 100$ & $1: 250$ & $1: 250$ & $1: 100$ & - \\
\hline 22 & - & - & - & - & - & 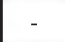 & & - & - & - & - & - & 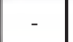 & 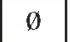 & 0 & 0 & $\emptyset$ \\
\hline 23 & - & - & - & - & $1: 50$ & 1:100 & 1:100 & $1: 100$ & $1: 50$ & - & - & - & - & - & - & - & - \\
\hline 24 & - & - & - & $1: 100$ & $1: 100$ & $1: 100$ & 1:100 & $1: 100$ & $1: 50$ & 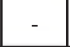 & $1: 25$ & $1: 25$ & $1: 25$ & $1: 50$ & 1:100 & - & - \\
\hline 25 & - & - & - & 1:50 & $1: 100$ & $1: 250$ & 1:250 & $1: 250$ & $1: 100$ & $1: 100$ & $1: 50$ & $1: 25$ & $1: 25$ & $1: 100$ & $1: 25$ & - & - \\
\hline 26 & - & & & $1: 100$ & $1: 250$ & $1: 500$ & $1: 250$ & $1: 250$ & $1: 100$ & $1: 100$ & $1: 100$ & $1: 100$ & $1: 50$ & $1: 50$ & $1: 25$ & $1: 25$ & \\
\hline
\end{tabular}

Legend: (-) negative $\quad(+)$ positive $\emptyset$-died rabbits

The results of examination of 183 blood sera of rabbits infected via skin scarification and rubbing of live cultures of $L$. hardjo (Table 1) revealed seropositive finding in $67(36.61 \%)$ samples. Monitoring of the increase of geometric mean titre (GMT) of $L$. hardjo specific antibodies, positive titre result was diagnosed on day 9 post infection (Chart 1). Monitoring of antibody titre values of rabbits during the further course of infection revealed that they persisted at the weakly-positive level (1:100) until day 17 post challenge, when the titre values dropped below the lower limits of positivity of MA method (titre $<1: 100)$. 


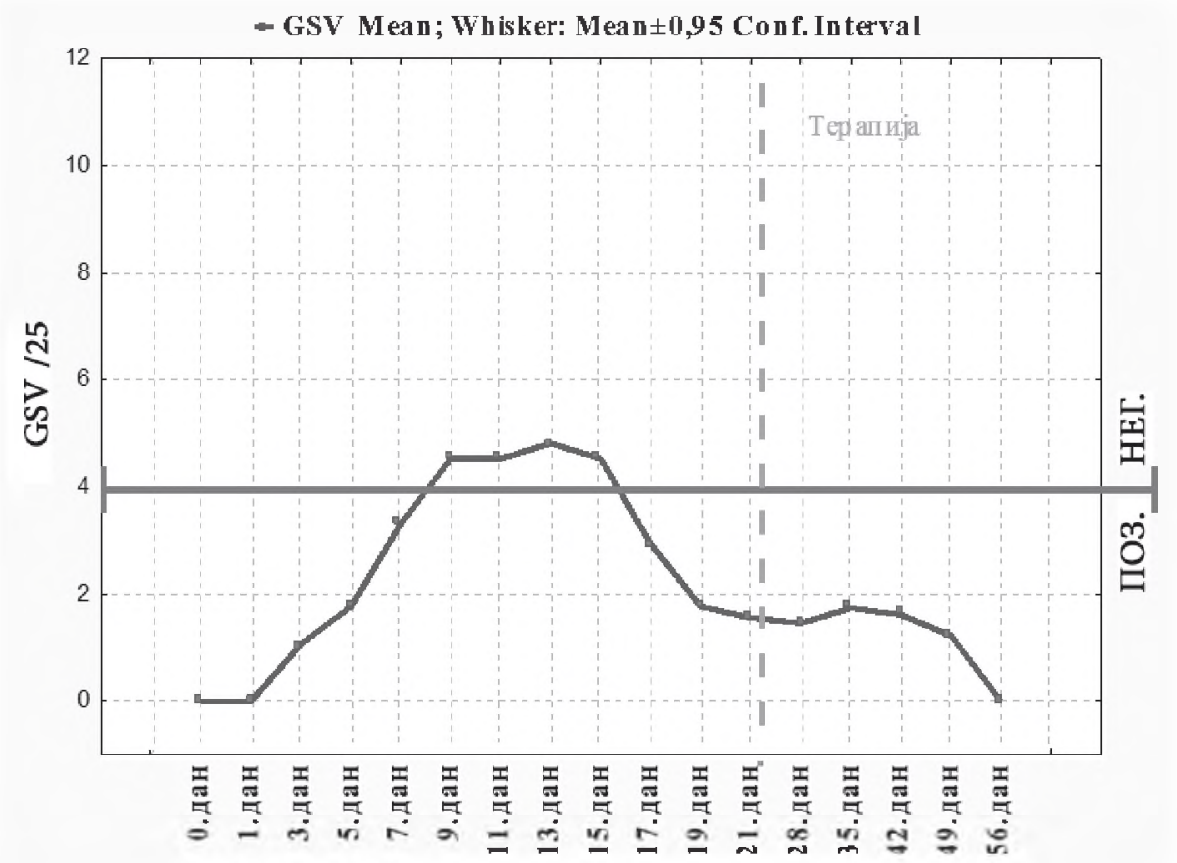

Chart 1. Distribution of GMT antibodies against $L$. hardjo in blood sera of rabbits challenged by skin scarification (microscopic agglutination method, MA).

Collected rabbit serum samples were also examined in an immunoenzyme assay, ELISA. L. hardjo antibody finding obtained by ELISA revealed positive result in $67(36.61 \%$ ) samples (rate $>45 \%$ ), and suspect result (rate 20-45\%) in $18(9.84 \%)$ samples. In this test, the earliest diagnosis of seropositive result was accomplished on day 7 (Table 2). Monitoring of distribution of geometric mean titre values revealed that titre of $\mathrm{L}$. hardjo specific antibodies exceeds the boundary positivity level on day 15 post challenge. The highest GMT value was recorded on $42^{\text {nd }}$ day of investigation period, showing decreasing tendency in the following days (Chart 2). 
Table 2. Finding of antibodies against $L$. hardjo in blood serum of rabbits challenged by skin scarification - ELISA (expressed in \%)

\begin{tabular}{|c|c|c|c|c|c|c|c|c|c|c|c|c|c|c|c|c|c|}
\hline \multirow{2}{*}{$\stackrel{\dot{0}}{\stackrel{E}{E}}$} & \multicolumn{12}{|c|}{ Days post infection } & \multicolumn{5}{|c|}{ Days post therapy } \\
\hline & 0 . & 1. & 3. & 5. & 7. & 9. & 11. & 13. & 15. & 17. & 19. & 21. & 28. & 35. & 42. & 49. & 56. \\
\hline 1 & $13 \%$ & $5 \%$ & $10 \%$ & $5 \%$ & $16 \%$ & $13 \%$ & $24 \%$ & $16 \%$ & $21 \%$ & $2 \%$ & $13 \%$ & $19 \%$ & $25 \%$ & $63 \%$ & $124 \%$ & $40 \%$ & $129 \%$ \\
\hline 2 & $2 \%$ & $4 \%$ & $6 \%$ & $7 \%$ & $4 \%$ & $2 \%$ & $2 \%$ & $3 \%$ & $7 \%$ & $0 \%$ & $13 \%$ & $4 \%$ & $22 \%$ & $47 \%$ & $94 \%$ & $77 \%$ & $33 \%$ \\
\hline 3 & $12 \%$ & $3 \%$ & $13 \%$ & $4 \%$ & $4 \%$ & $-2 \%$ & $1 \%$ & $0 \%$ & $5 \%$ & $0 \%$ & $6 \%$ & $3 \%$ & $29 \%$ & $66 \%$ & $128 \%$ & $72 \%$ & $98 \%$ \\
\hline 4 & $4 \%$ & $6 \%$ & $4 \%$ & $13 \%$ & $19 \%$ & $8 \%$ & $8 \%$ & $9 \%$ & $13 \%$ & $13 \%$ & $25 \%$ & $28 \%$ & $31 \%$ & $57 \%$ & $145 \%$ & $124 \%$ & $129 \%$ \\
\hline 5 & $1 \%$ & $4 \%$ & $1 \%$ & $13 \%$ & $3 \%$ & $9 \%$ & $9 \%$ & $15 \%$ & $17 \%$ & $-3 \%$ & $36 \%$ & $39 \%$ & $44 \%$ & $69 \%$ & $103 \%$ & $90 \%$ & $89 \%$ \\
\hline 21 & $1 \%$ & $-6 \%$ & $-5 \%$ & $3 \%$ & $5 \%$ & $6 \%$ & $8 \%$ & $18 \%$ & $94 \%$ & $116 \%$ & $114 \%$ & $127 \%$ & $110 \%$ & $93 \%$ & $112 \%$ & $91 \%$ & $85 \%$ \\
\hline 22 & $-3 \%$ & $-2 \%$ & $-7 \%$ & $25 \%$ & $4 \%$ & $6 \%$ & $3 \%$ & $1 \%$ & $48 \%$ & $19 \%$ & $39 \%$ & $27 \%$ & $31 \%$ & W & W & W & W \\
\hline 23 & $0 \%$ & $-1 \%$ & $-1 \%$ & $-1 \%$ & $3 \%$ & $2 \%$ & $1 \%$ & $3 \%$ & $92 \%$ & $65 \%$ & $81 \%$ & $90 \%$ & $106 \%$ & $130 \%$ & $118 \%$ & $123 \%$ & $91 \%$ \\
\hline 24 & $-4 \%$ & $7 \%$ & $5 \%$ & $3 \%$ & $5 \%$ & $21 \%$ & $29 \%$ & $32 \%$ & $72 \%$ & $46 \%$ & $127 \%$ & $107 \%$ & $115 \%$ & $124 \%$ & $149 \%$ & $125 \%$ & $135 \%$ \\
\hline 25 & $14 \%$ & $-2 \%$ & $13 \%$ & $16 \%$ & $76 \%$ & $52 \%$ & $43 \%$ & $50 \%$ & $124 \%$ & $101 \%$ & $109 \%$ & $77 \%$ & $99 \%$ & $114 \%$ & $108 \%$ & $102 \%$ & $97 \%$ \\
\hline 26 & $1 \%$ & $-3 \%$ & $-5 \%$ & $3 \%$ & $0 \%$ & $5 \%$ & $4 \%$ & $11 \%$ & $54 \%$ & $88 \%$ & $109 \%$ & $98 \%$ & $82 \%$ & $113 \%$ & $174 \%$ & $120 \%$ & $109 \%$ \\
\hline
\end{tabular}

\section{Legend: (-) negative $\quad(+)$ positive $\quad \emptyset$-died rabbits}

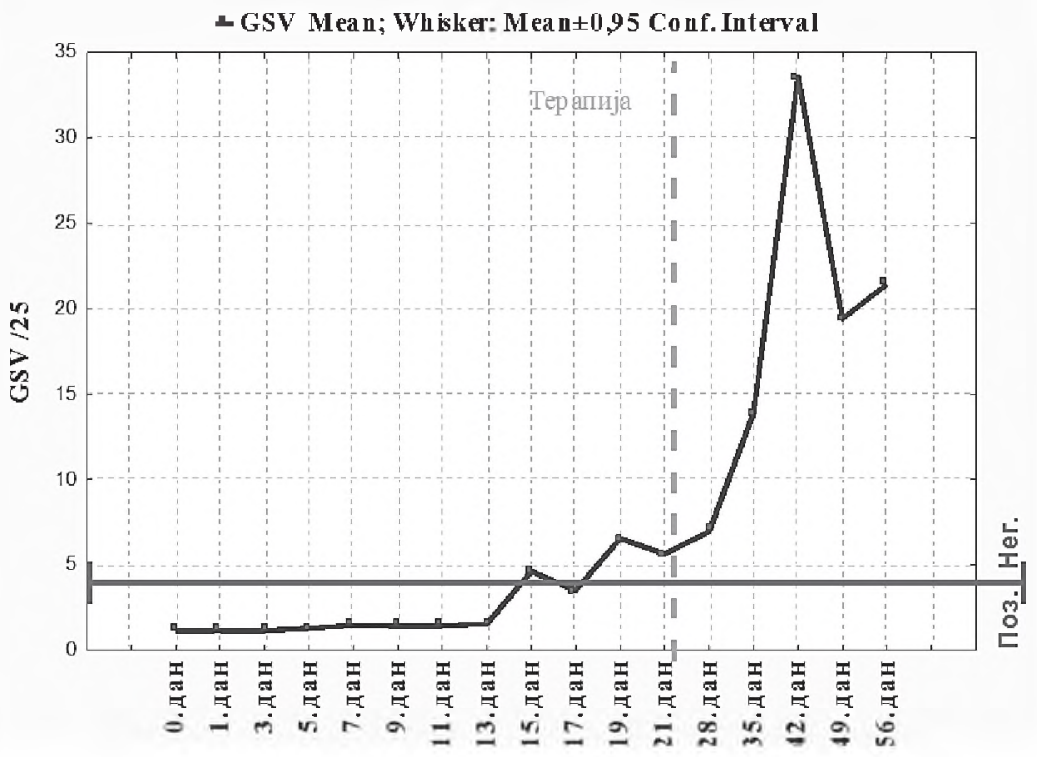

Chart 2. Distribution of GMT antibodies against $L$. hardjo in blood sera of rabbits challenged by skin scarification - diagnosed by ELISA 
Comparison of GMT values obtained by MT and ELISA tests revealed the following: samples examined by MA test manifested increased levels of specific antibodies, which exceeded the boundary level of 1:100) (GMT titre 4 $\log 2 /{ }_{25}$ ) as early as on day 7 . The level of $L$. hardjo specific antibodies diagnosed by MA method increases until reaching the maximum level on days 13 and 15, and then shows decreasing tendency and drops below the boundary positivity level on day 42 (Cole J.R.Jr,et al.1973). Contrary to MA method, ELI$S A$ demonstrated considerably longer period ( 15 days) between the infection and exceeding the boundary positivity levels being $45 \%(P P)$ or (GMT titre 4 $\log 2 /{ }_{25}$ ). During the further course of the experiment, GMT values manifested permanent increasing tendency until day 42 , when they reached the maximum levels, and then started to drop down gradually. It is to be emphasized that MA method enables seropositivity diagnosis from day 7 to day 42 postinfection. In ELISA, the time span of diagnosis extends from day 15 to day 56 , i.e. to the end of the investigation period (Chart 3).

Chart 3. Distribution of $G M T$ values for antibodies against $L$. hardjo in blood sera of rabbits challenged by skin scarification - diagnosed by MA test and ELISA

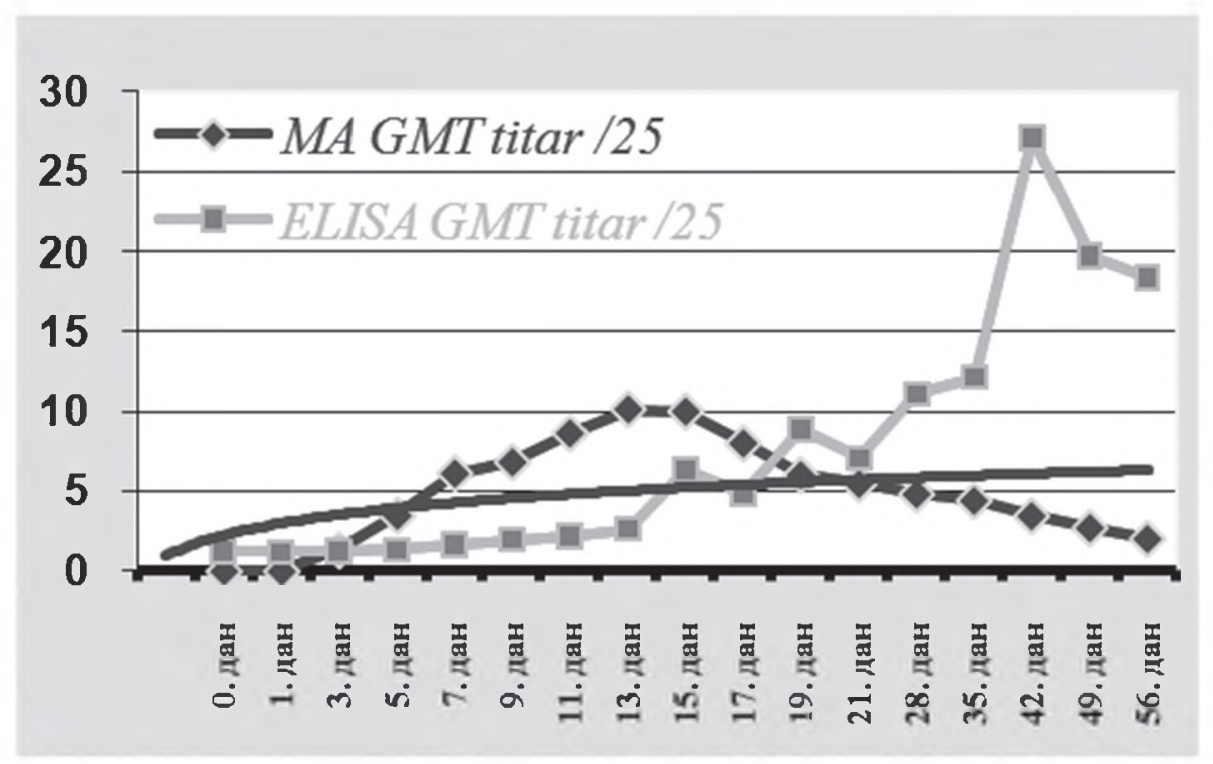

Testing of correlation levels of GMT values for the applied methods ( i.e. MA and ELISA) in the population of rabbits challenged by skin scarification revealed weak inverse linear correlation of $r=-0.3277$ with 0.05 level of 
significance. Furthermore, the parity of arithmetic means of GMT values for MA test and ELISA was tested and $t$-value $(t=-2.288)$ and $P$ value $0.029(P$ $<0.05)$ were calculated, indicating mutual difference between the arithmetic means of tested sets with a risk of 0.05 (Merien F.et al.1995;Márcia Costa Ooteman et al.2006; Grgić Ž et al. 2007).

Analysis of the results obtained by the method of isolation on culture media, L. hardjo was isolated from $33(18.03 \%)$ out of 183 examined blood sera of rabbits challenged via skin scarification. Using the isolation method, $L$. hardjo was detected as early as the day 3 post-challenge, and the highest rate of positive findings was recorded on day 17 post-infection. The results are presented in Table 3 (Schonberg A.,et al. 199.;Johnson R. C. Et al.1973).

Table 3. Results of reisolation of $L$. hardjo from blood of rabbits challenged via skin scarification using cultivation in liquid and semisolid medium acc. to Johnson supplemented with $200 \mu \mathrm{g} / 1 \mathrm{ml} 5 \mathrm{FU}$.

\begin{tabular}{|c|c|c|c|c|c|c|c|c|c|c|c|c|c|c|c|c|c|}
\hline \multirow{2}{*}{$\begin{array}{l}\dot{0} \\
\dot{z} \\
\dot{E}\end{array}$} & \multicolumn{12}{|c|}{ Days post infection } & \multicolumn{5}{|c|}{ Days post therapy } \\
\hline & 0. & 1. & 3. & 5. & 7. & 9. & 11. & 13. & 15. & 17. & 19. & 21. & 28. & 35. & 42. & 49. & 56. \\
\hline 1 & - & - & - & - & - & - & - & - & + & + & - & - & - & - & - & - & - \\
\hline 2 & - & - & - & - & - & - & - & - & + & + & - & - & - & - & - & - & - \\
\hline 3 & - & - & - & - & - & - & - & + & + & + & + & + & - & - & - & - & - \\
\hline 4 & - & - & - & - & - & - & - & - & + & + & + & - & - & - & - & - & - \\
\hline 5 & - & - & - & - & - & - & + & + & + & - & - & - & - & - & - & - & - \\
\hline 21 & - & - & + & - & - & - & + & + & - & + & - & + & - & - & - & - & - \\
\hline 22 & - & - & - & - & - & - & - & + & + & + & - & - & - & $\mathbf{W}$ & W & W & W \\
\hline 23 & - & - & - & - & - & - & - & + & - & + & + & + & - & - & - & - & - \\
\hline 24 & - & - & - & - & - & - & - & + & - & + & + & - & - & - & - & - & - \\
\hline 25 & - & - & - & - & - & - & - & - & + & - & - & - & - & - & - & - & - \\
\hline 26 & - & - & - & - & - & - & - & - & + & + & - & - & - & - & - & - & - \\
\hline$\Sigma$ & 0 & 0 & $\begin{array}{c}1 \\
9,09 \%\end{array}$ & 0 & 0 & 0 & $\begin{array}{c}2 \\
18,18 \%\end{array}$ & $\begin{array}{c}6 \\
54,54 \%\end{array}$ & $\begin{array}{c}8 \\
72,73 \%\end{array}$ & $\begin{array}{c}9 \\
81,82 \%\end{array}$ & $\begin{array}{c}4 \\
36,36 \%\end{array}$ & $\begin{array}{c}3 \\
27,27 \%\end{array}$ & 0 & 0 & 0 & 0 & 0 \\
\hline
\end{tabular}

Legend: liquid medium o Semisolid o, liquid + semisolid o dead rabbit W positive $(+)$ negative $(-)$ 
The presence of $L$. hardjo in blood of infected rabbits was also examined using the method of polymerase chain reaction (PCR). L. hardjo was detected in $67(56.30 \%)$ out of 119 examined samples. By the use of PCR, L. hardjo was detected as early as on day 1 , and the highest rate of positive findings was observed on day 19 post-challenge (Table 4). The method of polymerase chain reaction enabled detection of $L$. hardjo also in the second stage of the experiment, i.e. after administration of antimicrobial therapy, which is an important point for the interpretation of the results obtained in this assay. Polymerase chain reaction method demonstrated high sensitivity, that is, ability of detecting 5-10 bacteria per $1 \mathrm{ml}$ of the sample as well as short time of examination, which makes it more appropriate than the method of cultivation (Gerritsen $M$. J. et al.1991; Grgić Ž. et al. 2012).

Table 4. Finding of $L$. hardjo in the sera of rabbits infected via skin scarification using the PCR method

\begin{tabular}{|c|c|c|c|c|c|c|c|c|c|c|c|c|c|c|c|c|c|}
\hline \multirow{2}{*}{$\begin{array}{c}\dot{\vec{z}} \\
\dot{z} \\
\dot{\xi}\end{array}$} & \multicolumn{12}{|c|}{ Days post infection } & \multicolumn{5}{|c|}{ Days post therapy } \\
\hline & 0. & 1. & 3. & 5. & 7. & 9. & 11. & 13. & 15. & 17. & 19. & 21. & 28. & 35. & 42. & 49. & 56. \\
\hline 1 & - & - & - & - & - & - & - & + & + & + & + & + & + & + & - & + & + \\
\hline 2 & - & - & - & - & - & - & + & - & + & + & + & + & + & + & + & + & + \\
\hline 3 & - & - & - & - & + & + & - & + & + & + & + & + & - & + & + & + & + \\
\hline 4 & - & + & - & + & - & - & - & + & + & - & + & + & + & + & + & - & - \\
\hline 5 & - & - & - & - & + & - & + & + & + & + & + & - & - & - & - & - & - \\
\hline 21 & - & + & + & + & + & + & + & + & - & + & + & + & + & + & + & + & + \\
\hline 24 & - & - & - & - & - & + & - & + & - & + & + & + & - & + & + & - & - \\
\hline$\Sigma$ & 0 & 2 & 1 & 2 & 3 & 3 & 3 & 6 & 5 & 6 & 7 & 6 & 4 & 6 & 5 & 4 & 4 \\
\hline & & $28,57 \%$ & $14,29 \%$ & $28,57 \%$ & $42,85 \%$ & $42,85 \%$ & $42,85 \%$ & $85,71 \%$ & $71,43 \%$ & $85,71 \%$ & $100 \%$ & $85,71 \%$ & $57,14 \%$ & $\mid 85,71 \%$ & $71,43 \%$ & $57,14 \%$ & $57,14 \%$ \\
\hline
\end{tabular}

Legend: $P C R$ positive (+) $P C R$ negative (-).

Numerous authors (Maria Rosa et al. 2005; Cousins D.V., 1991) reported on the capacities of ELISA and its advantages over the MA method (Brown P.D, 1995 and Cousins D.V., et al., 1991). In that respect, our results should contribute to better understanding of this diseases as well as evaluation of the validity of the applied diagnostic methods. In our research, microscopic agglutination method (agglutination-lysis test) was the basic assay, which in recent 
period underwent certain modifications aimed at improving the reliability of ELISA method (Cole et al., 197; Márcia Costa Ooteman et al.,2006). The articles of Bercovich Z. et al. (1990) and Levett P.N. (2002) confirmed the ability of this method to detect specific antibodies in the serum of infected animals at the earliest between the day 5 and day 10 post-challenge, which corresponds with our results. The method of cultivation of leptospires is highly reliable; however, it manifests some considerable limitations such as poor stability of leptospires and their rapid decay in the environment, time-consuming isolation procedure as well as high level of biohazard for the personnel. The method of polymerase chain reaction (PCR) enables detection of leptospiral infection at a very early stage thus increasing the chance for prompt and successful therapy. This is of particular importance in latent human and animal infections and their suppression and prevention. Data from the available literature pertaining to comparison of the results obtained by PCR and other methods strongly indicated its high sensitivity as compared to other methods used so far in the diagnostics of leptospirosis (Gravekamp et al., 1993; Grgić Ž., 2011, Doctoral Dissertation).

\section{LITERATURE}

1. Bercovich Z., Taaijke R. and Bokhout B.A.; Evaluation of an ELISA for the Diagnosis of Experimentally Induced and Naturally Occurring Leptospira hardjo Infection in Cattle; Vet. Microbiol.; 21(3); 255-262, Jan. 1990.

2. Brown P.D., Gravekamp C., Carrington D.G., Van-De-Kemp H.; Hartskeerl R.A., Edwards C.N., Everard C.O.R., Terpstra W.J., Levett P.N.*; Evaluation of the polymerase chain reaction for early diagnosis of leptospirosis; J.MED.-MICROBIOL. vol. 43, no. 2, pp. 110 - 114; 1995.

3. C. Gravekamp, H. van De Kemp, D. Franzen, D. Carrington, G.J. Schoone, G.J.J.M. Van Eys, C.O.R. Everard, R.A. Hartskeerl and W.J. Terpstra, Detection of seven species of pathogenic leptospires by PCR using two sets of primers, Journal of General Microbiology 139, pp. 1691-1700, 1993.

4. Cole J.R.Jr, Sulzer C.R. and Purchell A.R.; Improved microtechnique for the leptospiral microscopic agglutination test. Appe. Microbiol. 25; 9761980, 1973.

5. Cousins D.V., Robertson G.M., Parkinson J. and Richards R.B.; Use of the Enzyme Link Immunosorbent Assay (ELISA) to Detect the IgM and IgG Antibody Response to Leptospira interrogans Serovar hardjo in Pregnant Ewes;l Zbl. Bakt. 275 (3), 335-342, 1991. 
6. Gerritsen M. J., Olyhoek T., Smits M. A. and bokhhout B. A.; Sample preparation for polymerase chain reaction-based semiquantitative detection of Leptospira interrogans serovar hardjo subtype hardjobovis in bovine urine, Journal of Clinical Microbiology, Vol. 29, No 12, p 2805-2808, 1991.

7. Grgić Ž., Đuričić B., Vidić B., Savić S., Pušić I.: Application of polymerase chain reaction (PCR)in detection of L.interrogans serotype hardjo in cattle = Primene lančane reakcije polimeraze (PCR)u dokazivanju L.interrogans serotype hardjo kod goveda.Proceedings, Second International epizootiology Symposium [i]XIV Serbian epizootiology days, April 18-21, 2012, Belgrade, glavni i odgovorni urednik Tamaš Petrović, Beograd, SVD, Sekcija za zoonoze, 2012, Str.108-116, ISBN 978-86-83115-20-4 (eng), M33 1,0

8. Grgić Ž., Đuričić B., Vidić B., Savić-Jevdenić S.: Uporedna ispitivanja komercijalnog i modifikovanih elisa testova u dijagnostici L.hardjo kod goveda = A commparatfve examination of comercial and modified elisa test for a diagnostic of L.hardjo in cattle.Zbornik radova i kratkih sadržaja, IX epizootiološki dani sa međunarodnim učešćem, Požarevac 28-31.mart 2007.godine, urednik Bosiljka Đuričić, Beograd, SVD, Sekcija za zoonoze, 2007, str.208-211, ISBN 978-86-83115-07-5 (srp), M64 0,2

9. Grgić Ž.: Uporedno ispitivanje bakterioloških i seroloških metoda i polimeraza lančane reakcije u dijagnostici leptospiroze goveda = Comparative Investigation of Bacteriological and Serological Methods and Polymerase Chain Reaction in the Diagnostics of Leptospirosis in Cattle : doktorska disertacija.Beograd, Fakultet veterinarske medicine, Katedra za zarazne bolesti životinja i bolesti pčela, 2011 M71 6,0

10. Johnson R. C., Walby J., Henry R. A. and Auran N. F.: Cultivation of parasitic leptospires: effect of pyruvate. Applied Microbiology. 26: 118-11, 1973.

11. Levett P.N., Branch S. L.; Evaluation of two enzume-linked immunosorbent assay methods for detection of immunoglobulin $M$ amtibodies in acute leptospirosis; Am. J. Trop. Med. Hyg., Vol 66, 6, p 745-748, 2002.

12. Márcia Costa Ooteman, Annamaria Ravara Vago and Matilde Cota Koury; Evaluation of MAT, IgM ELISA and PCR methods for the diagnosis of human leptospirosis; Journal of Microbiological methods Vol. 65, 2, p 247-257, may 2006.

13. Merien F., Baranton G., Perolat P.; Comparison of polymerase chain reaction with microagglutination test and culture for diagnosis of leptospirosis; J.-INFECT.-DIS. vol. 172, no. 1, pp. 281-285, 1995.

14. Schonberg A., Hahn Hey B., Kampe U., Schmidt K., Ellis W.A.; The isolation and identification of Leptospira interrogans serovar bratislava from a pig in Germany; Zentralbl-. Veterinarmed-B, Vol. 39, No 5, p 362-368, 1992. 
15. Smith, C.R., Ketterer, P.J., McGowan, M.R. and Corney, B.G.: Areview of laboratory techniques and their use in the diagnosis ofLeptospira interrogans serovar hardjo infection in cattle. Aust. Vet.J.; 71, (9): 290-294., 1994.

Received / Primljeno: 10.01.2014.

Accepted / Odobreno: 25.01.2014. 
Archives of Veterinary Medicine, Vol. 6, No. 2, 71 - 85, 2013. Grgić Ž. i dr.: Comparative investigation ... 